$12-2016$

\title{
Spatiality of the Stages of Genocide: The Armenian Case
}

Shelley J. Burleson

Texas State University - San Marcos

Alberto Giordano

Texas State University-San Marcos, Department of Geography

Follow this and additional works at: https://digitalcommons.usf.edu/gsp

\section{Recommended Citation}

Burleson, Shelley J. and Giordano, Alberto (2016) "Spatiality of the Stages of Genocide: The Armenian Case," Genocide Studies and Prevention: An International Journal: Vol. 10: Iss. 3: 39-58.

DOI:

http://doi.org/10.5038/1911-9933.10.3.1410

Available at: https://digitalcommons.usf.edu/gsp/vol10/iss3/6

This Articles is brought to you for free and open access by the Open Access Journals at Digital Commons @ University of South Florida. It has been accepted for inclusion in Genocide Studies and Prevention: An International Journal by an authorized editor of Digital Commons @ University of South Florida. For more information, please contact digitalcommons@usf.edu. 
Spatiality of the Stages of Genocide: The Armenian Case

\author{
Shelley J. Burleson \\ Texas State University - San Marcos \\ San Marcos, Texas, USA \\ Alberto Giordano \\ Texas State University - San Marcos \\ San Marcos, Texas, USA
}

\begin{abstract}
This article describes the construction of a historical GIS (HGIS) of the Armenian genocide and its application to study how the genocide unfolded spatially and temporally using stage models proposed by Gregory Stanton. The Kazarian manuscript provided a daily record of events related to the genocide during 1914-1923 and served as a primary source. Models outlining and describing the stages of genocide provide a structured and vetted approach to studying the spatial and temporal aspects of the genocidal process, especially genocide by attrition. This article links HGIS to a qualitative, historical source and describes the uncertainties that arise when mapping historical events. While the genocide literature is abundant in areas related to theory and practice, examples of explicitly spatial analyses are lacking. Our contribution aims at filling this gap.
\end{abstract}

Keywords: Armenian genocide, genocide stages, genocide by attrition, geographies of genocide, Historical GIS

\title{
Introduction
}

The term genocide describes destructive actions undertaken with the purposeful intent to destroy a specific group of people based on some perceived difference - usually racial or religious. Although this definition excludes cultural and political genocide, it serves as a starting point to describe processes designed to annihilate a group of people. Indeed, genocide pioneer Raphael Lemkin himself advocated for recognition of the importance of culture to the heritage of nations and called for international protection of cultures as well as peoples. ${ }^{1}$ Lemkin asserted that genocidal processes not only destroy groups of people, but also eradicate cultural markers, such as the languages, place names, and signs and symbols of the targeted group. ${ }^{2}$ While Lemkin's broad views concerning the nature of genocide were not instantiated into international law, recently there has been a renewed scholarly interest in studying genocides as broader phenomena and shedding light on obscured or hidden genocidal histories. ${ }^{3}$ One of these previously obscured, yet relatively massive genocides, the Armenian genocide, serves as the focus of this research. In the early twentieth century over one million Armenians were killed, along with tens of thousands of Christian Greeks and Assyrians in present-day Turkey. ${ }^{4}$ In this study, we use the theory of the stages of genocide outlined by Stanton ${ }^{5}$ to explore what spatial and temporal patterns emerge from the Armenian Genocide as narrated in what is known as the Kazarian Manuscript. ${ }^{6}$

Rosenberg argues that the link between genocide processes and perpetrator acts needs to guide research to expand further the field of genocide studies and possibly aid in the prevention of mass killings. ${ }^{7}$ In her study, Rosenberg focuses on the under-theorized concept of genocide by attrition, defined as a slow process of annihilation which relies primarily on indirect methods of destruction.

\footnotetext{
${ }^{1}$ Raphael Lemkin, “Genocide," American Scholar 15, no. 2 (1946), 227-230.

${ }^{2}$ Raphael Lemkin, “Genocide: A Modern Crime,” Free World 4 (1945), 39-43.

${ }^{3}$ See, for example, Barbara Harff, "No lessons learned from the Holocuast? Assessing Risks of Genocide and Political Mass Murder Since 1955," American Political Science Review 97, no. 1 (2003), 57-73; Ben Kiernan, Blood and Soil: A World History of Genocide and Extermination from Sparta to Darfur (New Haven: Yale University Press, 2009).

${ }^{4}$ Vahakn N. Dadrian, The History of the Armenian Genocide: Ethnic Conflict from the Balkans to Anatolia to the Caucasus (New York: Berghahn Books, 2003).

${ }^{5}$ Gregory H. Stanton, “The Eight Stages of Genocide," 1996, Genocide Watch, accessed October 16, 2016, http://www. genocidewatch.org/genocide/8stagesofgenocide.html; Gregory H. Stanton, "The Ten Stages of Genocide," 2013, Genocide Watch, accessed October 16, 2016, http://www.genocidewatch.org/genocide/tenstagesofgenocide.html.

${ }^{6}$ Haigazn K. Kazarian, A Chronology of the Armenian Genocide, trans. R.P. Adalian (Washington, DC: Armenian National Institute, 1923).

${ }^{7}$ Sheri P. Rosenberg, “Genocide is a Process, Not an Event," Genocide Studies and Prevention 7, no. 1 (2012), 16-23.
}

Shelley J. Burleson and Alberto Giordano, "Spatiality of the Stages of Genocide: The Armenian Case" Genocide Studies and Prevention 10, 3 (2016): 39-58. ๑2016 Genocide Studies and Prevention.

http://dx.doi.org/10.5038/1911-9933.10.3.1410 
In contrast to outright mass extermination, genocide by attrition allows a more passive role for perpetrators, who place victims into circumstances whereby disease, harsh climates, starvation, and dehydration cause massive casualties. ${ }^{8}$ Examples of activities that produce genocide through attritive processes include the enactment of discriminatory laws, policies, sanctions, and property confiscations aimed at isolating a segment of the population. Further, ambiguities in these laws and policies often confer broad discretion to mid-level perpetrators, who, stoked by discriminatory animi, wield such power to disastrous effect in pursuing the overarching goal of annihilation. A theoretical approach to studying the inner workings of genocide as a process is more easily conceptualized by defining stages that capture the progression of events that produce genocide. ${ }^{9}$

Geography can contribute to the understanding of genocide processes in several ways, ${ }^{10}$ including through a spatial analytical approach, which we adopt in our research. Some genocide research focuses on why mass murder occurs or on the detection and prevention of genocide, rather than how genocide progresses across territories. ${ }^{11}$ Shaw, among others, urges a restructuring of genocide studies toward a focus on the structures or processes that produce genocidal outcomes, rather than the subjectivity of perpetrators. ${ }^{12}$ In other work, ${ }^{13}$ we assign perpetrators to a macro, meso, or micro level of participation ${ }^{14}$ at geographic scales ranging from the national to the regional, to the province, district, and ultimately, village. The geography of genocide involves a myriad of power struggles and acts of resistance, as well as killings, aimed at achieving the ultimate objective of creating a utopia in place, for example, a nation to cause or facilitate violence in order to achieve a homogenous state. By analyzing genocidal processes through the lens of geographic scale, we hope to understand how perpetrators implemented genocide spatially and in stages in the pursuit of the development of a homogenous social order idealized by the Turkish government.

In our model, perpetrator roles fall into one of three levels ${ }^{15}$ at a plurality of scales. The macro-level includes government policy and decision-making processes at the national scale that ultimately lead to the destruction of a targeted population. The meso-level, or mid-level, includes active participation in the interpretation and enforcement of policies, procedures, and dictates at the regional, province, district, and village scales by organized groups such as, in the Armenian case, bands of government-sanctioned civilians known as chetes, often made up of Kurds. ${ }^{16}$ The micro-level involves individuals at the local or village scale that react violently towards individuals identified as the "other," in genocidal rhetoric, including at times friends and neighbors. By combining these perpetrator levels and geographic scales in the context of a stage model of

\footnotetext{
${ }^{8}$ Helen Fein, “Genocide by Attrition 1939-1993: The Warsaw Ghetto, Cambodia, and Sudan: Links between Human Rights, Health, and Mass Death," Health and Human Rights 2, no. 2 (1997), 10-45.

${ }^{9}$ See Helen Fein, Accounting for Genocide: Victims - and Survivors - of the Holocaust (New York: Free Press, 1979); see also Stanton, "The Eight Stages of Genocide"; Stanton, "The Ten Stages of Genocide."

${ }^{10}$ See e.g. Allan D. Cooper, The Geography of Genocide (Lanham: University Press of America, 2009); Anne Kelly Knowles, Tim Cole and Alberto Giordano, Geographies of the Holocaust (Bloomington: Indiana University Press, 2014); Marguerite Madden and Amy Ross, "Genocide and GIScience: Integrating Personal Narrative and Geographic Science to Study Human Rights," The Professional Geographer 61, no. 4 (2009), 508-526; Russell Schimmer, "Tracking the Genocide in Darfur: Population Displacement as Recorded by Remote Sensing," Yale Center for International and Area Studies: Genocide Studies Working Paper no. 36 (2008).

${ }^{11}$ See e.g. Israel W. Charny, How Can we Commit the Unthinkable? Genocide: The Human Cancer (Boulder: Westview Press, 1982); Daniel J. Goldhagen, Worse than War: Genocide, Eliminationism, and the Ongoing Assault on Humanity (New York: Public Affairs, 2009); Leo Kuper, Genocide: Its Political Use in the Twentieth Century (New Haven: Yale University Press, 1981); and James Waller, Becoming Evil: How Ordinary People Commit Genocide and Mass Killing (New York: Oxford University Press, 2007).

${ }^{12}$ Martin Shaw, "From Comparative to International Genocide Studies: The International Production of Genocide in 20thCentury Europe," European Journal of International Relations 18, no. 4 (2011), 645-668.

${ }^{13}$ Shelley Burleson and Alberto Giordano, "Extending Metadata Standards for Historical GIS Research: A Case Study of the Holocaust in Budapest and the Armenian Genocide in Turkey," International Journal of Applied Geospatial Research 6, no. 4 (2015), 88-109.

${ }^{14}$ Evgeny Finkel and Scott Straus, "Macro, Meso, and Micro Research on Genocide: Gains, Shortcomings, and Future Areas of Inquiry," Genocide Studies and Prevention: An International Journal 7, no. 1 (2012), 56-67.

${ }^{15}$ Ibid.

${ }^{16}$ Kazarian, A Chronology, entries for January 8, 1915 and April 16, 1915.
} 
genocide, the processes of genocide at varying spatial and temporal scales may be brought into sharper focus.

The technical and intellectual foundation for this application is derived from developments within the disciplines of geography and geographic information science (GIScience), including the emergence of historical geographical information systems (HGIS). Cole and Graham argue that prior to recent scholarship in geography, academics neglected spatial research and analysis of the Holocaust. ${ }^{17}$ We see a similar blank spot in scholarly geographic literature concerning the Armenian genocide. From this starting point, we aim to address this gap in the literature by adapting the stage model of genocide to produce a spatial analysis of the Armenian genocide. We seek to highlight the potential for-and the difficulties with-multi-disciplinary projects between HGIS and genocide studies. In recent scholarship, geographers have used applications and techniques to explore modern genocide including GIS, remote sensing, and virtual globes. Examples of genocide research using GIScience include Yale's Genocide Studies Program using remote sensing in Darfur, ${ }^{18}$ Madden and Ross's work combining GIS with personal narratives to describe the mass atrocities in Uganda, ${ }^{19}$ Verpoorten's work on excess mortality in Rwanda, ${ }^{20}$ and recent scholarship on the spatiality of the Holocaust. ${ }^{21}$ These developments parallel a trend toward incorporating qualitative source material into the traditionally quantitative methods of GIS that continues to grow within geography and GIScience. ${ }^{22}$ These examples help guide our methods and techniques for exploring the use of HGIS and personal narratives in the field of genocide studies.

\section{Genocide Stages as Structure}

Given the limited existing literature on the spatial processes involved in the production of genocide, our methodology relies on the defined and structured stages of genocide. Writing in the context of the Holocaust, Fein outlines five distinct stages as they relate to victims, which she argues occur sequentially: definition or identification, deprivation of rights and freedoms, segregation from the rest of the population, isolation, and finally, concentration. ${ }^{23}$ These five stages, Fein argues, preceded the actual mass extermination of the Holocaust. For a more articulated and satisfactory model (Table 1), we turned to the work of Gregory Stanton. ${ }^{24}$ Based on years of analysis of mass killings, including the Holocaust and other genocides, Stanton frames the progression of genocidal perpetration according to eight clearly defined stages: classification, symbolization, dehumanization, organization, polarization, preparation, extermination, and denial. ${ }^{25}$ In subsequent work, Stanton extends these original eight stages to include two additional ones-discrimination and persecution-bringing the total to ten discrete stages. ${ }^{26}$ Similar to Fein's model, Stanton argues that early stages occur before later stages; for instance, classification and symbolization precede

\footnotetext{
${ }^{17}$ Tim Cole and Graham Smith, "Ghettoization and the Holocaust: Budapest 1944," Journal of Historical Geography 21, no. 3 (1995), 300-316.

${ }^{18}$ Schimmer, "Tracking the Genocide in Darfur."

${ }^{19}$ Madden and Ross, "Genocide and GIScience."

${ }^{20}$ Marijke Verpoorten, “Detecting Hidden Violence: The Spatial Distribution of Excess Mortality in Rwanda," Political Geography 31, no. 1 (2012), 44-56.

${ }^{21}$ See e.g. Waitman Beorn et al., “The Geography of the Holocaust,” The Geographical Review 99, no. 4 (2009), 563-574; Alberto Giordano and Tim Cole, "On Place and Space: Calculating Social and Spatial Networks in the Budapest Ghetto," Transactions in GIS 15, no. s1 (2011), 143-170; see also Knowles, Cole and Giordano, Geographies of the Holocaust.

${ }^{22}$ See e.g. Meghan Cope and Sarah Elwood, eds., Qualitative GIS: A Mixed Method Approach (Los Angeles: Sage, 2009); Michael F. Goodchild and Donald G. Janelle, "Toward Critical Spatial Thinking in the Social Sciences and Humanities," GeoJournal 75, no. 1 (2010), 3-13; Jin-Kyu Jung and Sarah Elwood, "Extending the Qualitative Capabilities of GIS: Computer-Aided Qualitative GIS," Transactions in GIS 14, no. 1 (2010), 63-87; Madden and Ross, "Genocide and GIScience"; and Viswanath Venkatesh, Susan A. Brown, and Hillol Bala, "Bridging the QualitativeQuantitative Divide: Guidelines for Conducting Mixed Methods Resesarch in Information Systems," MIS Quarterly 37, no. 1 (2013), 21-54.

${ }^{23}$ Fein, Accounting for Genocide.

${ }^{24}$ Stanton, "The Eight Stages of Genocide."

${ }^{25} \mathrm{Ibid}$.

${ }^{26}$ Stanton, “The Ten Stages of Genocide."
} 
the preparation and extermination stages. However, Stanton also argues that all stages operate at various levels continuously throughout the duration of mass killing processes. We found this argument, and the ten-stage model, convincing and therefore rely on Stanton's ten stages of genocide to describe the progression and escalation of hostilities toward Armenians as perpetrated in and around present-day Turkey during the years 1914 to 1923. More specifically, our objective is to gain insight into the Armenian genocide by employing a spatial analytical perspective. During this period, the Turkish government implemented plans for the removal and destruction of ethnic minorities who remained within their borders following the rise of Turkish nationalism.

\section{Stages of the Armenian Genocide}

The beginning stages of genocide include the identification of a minority, however defined, that is perceived as being somehow different from the dominant group. Genocides thus begin with a classification (stage 1) phase, during which an us versus them mentality plays upon and amplifies preexisting social differences between the majority and minority groups (Table 1 ). When the slogan, "Turkey for Turks" began being used, this deceptively simplistic statement placed non-Turk ethnic groups squarely outside the accepted and dominant group. This call for a homogenous Turkey served to escalate violence toward various target groups perceived as being non-Turks.

The next stage stems from this classification process (stage 2) and consists of the exaggeration of stereotypes and the provocation of fear through symbols and propaganda. The Turks described Armenians and other targeted minority groups as internal enemies of the nation, characterizing them as unreliable, and prone to violence in order to stir fear and mistrust among their neighbors. Discrimination (stage 3) involves restrictions, often enforced through the enactment of prejudicial laws, designed to curtail the freedoms and liberties of the identified group. This stage includes illegal searches, seizures, and confiscations, as well as boycotts and closures of businesses. Local Turks targeted Armenian businesses for looting and burning, and seized Armenian schools and churches for garrisoning Turkish troops. Such discriminatory acts are then justified through the dehumanization (stage 4) of the targeted group who, using propaganda and symbols, is characterized as sub-human vermin who are sources of disease. The dehumanization stage is a crucial segue in the escalation of violence because it helps assuage the guilt of individual perpetrators, who would likely otherwise be reticent to persecute and murder people who were once neighbors and friends. These four stages target, identify, and marginalize a group of people in anticipation of ridding society of them.

The next three stages focus on policy and preparation from the top-down. Organization (stage 5) functions as a means for the state (or other authority structure) to issue genocidal orders - explicit or implied - to militias and other groups. In the Turkish context, the government ordered certain villages and districts be cleared of Armenians, but did not specify how, leaving the details to bands of armed militia. This ambiguity in instruction also provided a means of denying culpability after the fact if needed. Polarization (stage 6) serves to divide victim groups labelled as pariahs from society, through extremist activities, hate speeches, and continued propaganda. In the Turkish context, this stage involved the instilling of fear in the large moderate Turk population that otherwise likely opposed the targeting of their friends and neighbors. Preparation (stage 7) involves the planned and physical separation of victims, both from each other and from the general population. This stage outlines the processes involving the organized and methodical means of destruction of a group of identified victims. It includes the compiling of lists of individuals to arrest, routes for the movement of people, and planned methods of extermination.

The next two stages involve an escalation of physical violence against the targeted victim group. Persecution (stage 8 ) involves the intentional mistreatment of the targeted demographic. We consider this stage to routinely involve the production of genocide by attrition and in Turkey, this involved the spread of starvation, dehydration, illness, and disease amongst Armenians and other targeted social groups, that accompanied beatings and forced marches. This stage aids in the process of extermination (stage 9). Extermination describes the rapid and intentional mass murder of victims or, in a sense, the creation of spaces and places absent of the perceived other. Table 1 outlines Stanton's ten stages and includes a definition for each stage. 
Table 1. Stanton's ten-stage model with definitions (Stanton 1998, 2013).

\begin{tabular}{l|l}
\multicolumn{1}{c|}{ Original 8 Stages } & \multicolumn{1}{c}{ Definition } \\
\hline (1) Classification & $\begin{array}{l}\text { Members of a society are divided into groups referred to as us and them. This } \\
\text { division occurs because of differences in ethnicity, race, religion, nationality, culture, } \\
\text { or language and serves to drive the "us versus them" mentality needed to progress } \\
\text { further along in the stages of genocide. }\end{array}$ \\
\hline (2) Symbolization & $\begin{array}{l}\text { Derogatory names or symbols associated with the classified "them" in order to play } \\
\text { on the fears and insecurities of the dominant group. }\end{array}$ \\
\hline (4) Dehumanization & $\begin{array}{l}\text { The minority group shifts to pariah not worthy of life; dehumanization removes the } \\
\text { guilt and abhorrence of persecution and extermination by equating the minority } \\
\text { group as nothing more than vermin, animals, or disease. }\end{array}$ \\
\hline (5) Organization & $\begin{array}{l}\text { Generally, organization is top-down; policies are implemented by formal or informal } \\
\text { groups of militias. }\end{array}$ \\
\hline (6) Polarization & $\begin{array}{l}\text { Propaganda and hate groups intensify their attack on the minority groups in order to } \\
\text { further isolate them from societal norms. }\end{array}$ \\
\hline (7) Preparation & Planning and implementation of the mass murder of select groups of people. \\
\hline (9) Extermination & The culmination of all stages resulting in the mass killing of the identified other. \\
\hline (10) Denial & $\begin{array}{l}\text { The perpetrators insist no crimes were committed while actively destroying evidence } \\
\text { and assigning blame to the victims themselves. }\end{array}$ \\
\hline Additional 2 Stages & Definition \\
\hline (3) Discrimination & $\begin{array}{l}\text { Political power, laws, and customs used to control the targeted group and strips } \\
\text { them of basic rights, freedoms, and privileges. }\end{array}$ \\
\hline $\begin{array}{l}\text { Minority groups are identified and targeted for abuse, maltreatment, searches and } \\
\text { seizures, and forced into camps or deportation. }\end{array}$
\end{tabular}

\section{Sources and Methods}

Geographical Sources

We searched numerous map collections, including those of the Library of Congress and the Perry Castañeda Library at the University of Texas, for a map of Turkey dating between the mid1910s and the mid-1920s that was suitable for digitization, with accuracy and completeness levels appropriate for our purposes. Our search proved fruitless for the years 1910 to 1920, but we were able to locate suitable maps from before 1900 and after 1930. Figure 1 shows the administrative boundaries of the Ottoman Empire in 1899 according to a map from the Library of Congress collection. ${ }^{27}$ We used this map to compare the historical and current boundaries of Turkey.

For the period 1914 to 1923, we relied on Armenian genocide literature as a secondary source to aid us in establishing the boundaries of the areas most affected by the genocide; however, even within this relatively limited literature, we discovered disagreements in the location of provincial boundaries. For example, Hewsen's authoritative historical atlas of Armenia explicitly acknowledges vagueness and inaccuracies where data were missing or were incomplete..$^{28}$ Hovannisian's work includes a map of historic Armenian homelands, but its boundaries are difficult to read and at times tentatively placed, and the map itself only shows the eastern provinces. ${ }^{29}$ Akçam's book on the Armenian genocide does not include maps, ${ }^{30}$ but a 2006 monograph by the same author opens with a map by Ara Sarafian from the Gomidas Institute; however, as with other maps, the boundaries appear uncertainly drawn. ${ }^{31}$ The Armenian National Institute's maps illustrating the Armenian genocide are by far the most detailed, but they primarily show the eastern provinces, and again with a certain degree of uncertainty. ${ }^{32}$ Melkonian describes historical Armenia, from

\footnotetext{
${ }^{27}$ R. Huber, “Empire Ottoman: Division Administrative," Library of Congress, 1899, accessed October 10, 2015, https:// lccn.loc.gov/2007633930.

${ }^{28}$ Robert H. Hewsen, Armenia: A Historical Atlas (Chicago: University of Chicago Press, 2001).

${ }^{29}$ Richard G. Hovannisian, Remembrance and Denial: The Case of the Armenian Genocide (Detroit: Wayne State University Press, 1998)

${ }^{30}$ Taner Akçam, From Empire to Republic: Turkish Nationalism and the Armenian Genocide (London: Zed Books, 2004).

${ }^{31}$ Taner Akçam, A Shameful Act: The Armenian Genocide and the Question of Turkish Responsibility (New York: Henry Holt \& Co., 2006).

${ }^{32}$ Armenian National Institute, "Map of the 1915 Armenian Genocide in the Turkish Empire," accessed March 11, 2016,
} 


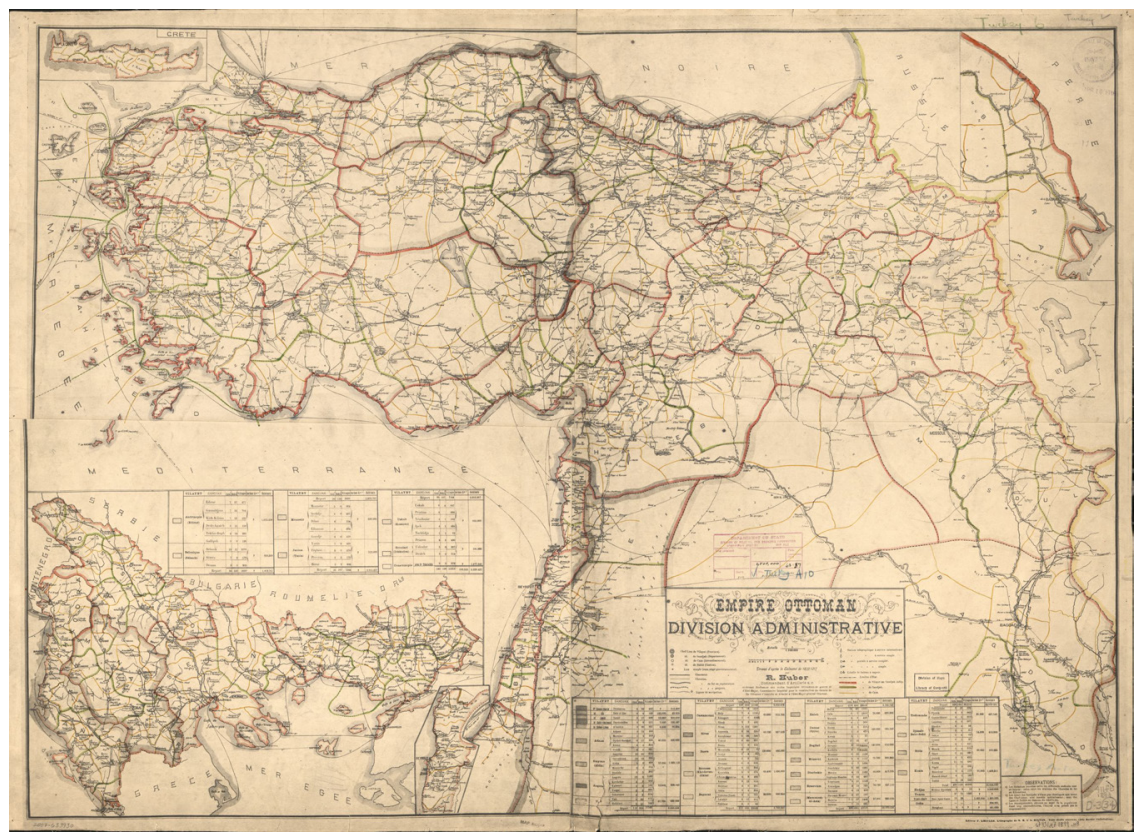

Figure 1. Ottoman Empire Administrative Divisions (1899).

Tbilisi to Erevan, as holding a population of 1.1 million Armenians, which coincides with sources claiming that the eastern provinces of Turkey contained the highest concentration of this population. ${ }^{33}$ In comparison, in his memoir, el-Ghusein claims that the number of Armenians living in the entire Ottoman Empire did not exceed 1.9 million. ${ }^{34}$ These examples highlight the uncertainty and ambiguity of sources related to the provincial boundaries of the Ottoman Empire and the Armenian population in present-day Turkey at the time.

Due to the scarcity of primary geographic sources for the years 1914 to 1923 and the lack of agreement amongst secondary sources, we combined maps created after the fact with readily available contemporary GIS datasets. Taking advantage of free downloadable files from DIVAGIS, ${ }^{35}$ we then built a GIS of the entire region that includes modern-day Turkey, Syria, Iraq, and surrounding countries. In the end, we created our own base map for use in the HGIS, acknowledging a degree of uncertainty in the location of provincial boundaries where appropriate (Figure 2). Our reconstruction is based on modern-day GIS layers of the region, maps from the literature, and maps from the pre-genocidal era, such as the 1899 map from the Library of Congress collection referenced above. In our reconstruction, we placed an emphasis on ensuring that villages referred to in the Kazarian manuscript fell within the correct province. ${ }^{36}$

\section{Data Sources}

Making use of a rich collection of qualitative sources such as memoirs, oral histories, interviews, and diaries, adds another dimension of detail to quantitative research of the type commonly associated with GIS. ${ }^{37}$ In this case study, we use the historical manuscript written by Haigazn K. Kazarian

http://www.armenian-genocide.org/map-full.html.

${ }^{33}$ Ashot Melkonian, Javakhk: Historical Outline, trans. T. Sonentz-Papazian (Boston: HyBooksOnline, 2009).

${ }^{34}$ Fa'iz el-Ghusein, Martyred Armenia (New York: George H. Doran Company, 1918).

${ }^{35}$ DIVA-GIS, accessed September 25, 2015, http://www.diva-gis.org/gdata.

${ }^{36}$ Kazarian, A Chronology.

${ }^{37}$ See e.g. Marc Gonzalez-Puente, Minerva Campos, Mike K. McCall and Jose Munoz-Rojas, “Places Beyond Maps: Integrating Spatial Map Analysis and Perception Studies to Unravel Landscape Change in a Mediterranean Mountain Area (NE Spain)," Applied Geography 52 (2014), 182-190; Madden and Ross, "Genocide and GIScience"; Jennet Seegers and Alberto Giordano, "Cartographic Constructs: A Case Study of Nantucket Island Oral Histories," The Professional 


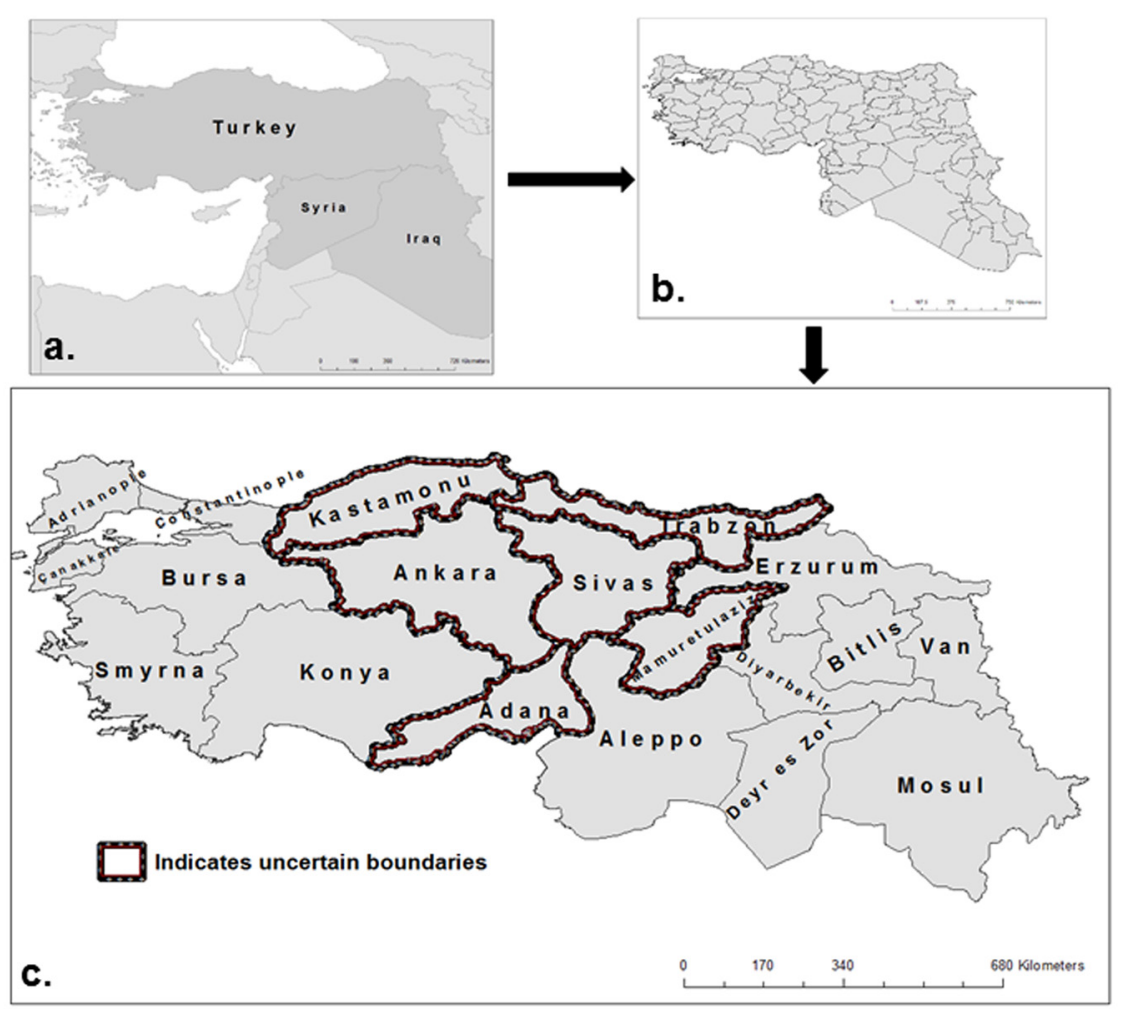

Figure 2. Map a. shows the modern borders for Turkey, Syria, and Iraq. Map b. shows the modern province boundaries for Turkey, Syria, and Iraq. Map c. shows the 1914 province boundaries for Turkey and the base map for our case study.

which covers the years 1914 to 1923 as a source to study the spatio-temporal patterns of the stages of the Armenian genocide. ${ }^{38}$ Kazarian worked as a journalist in Constantinople during the Armenian genocide and, later, served under the British with access to Turkish government documents. In its original form, the manuscript consists of two main components: dates and narrative descriptions of events recorded for each date. Kazarian recorded his perception and interpretation of events based on newspaper articles; government edicts, decrees, and speeches; and personal accounts from people returning to Constantinople from the countryside. The Armenian National Institute in Washington, D.C. stands firmly behind the validity of the Kazarian manuscript as a reliable source $^{39}$ as do the Armenian Genocide Resource Center of Northern California and the University of Minnesota Center for Holocaust and Genocide Studies, which both make the manuscript available as a teaching resource. Kazarian himself wrote extensively on the Armenian experience in Turkey, and scholars continue to reference him in their research..$^{40}$

For our work, we began by entering the web version of the translated manuscript into Microsoft Excel. We then added a geographical dimension by assigning the events described in the narrative to one or more of six distinct geographical scales-village, district, province, region, national, and global. We also assigned each event to a perpetrator level of participation at the

\footnotetext{
Geographer 67, no. 4 (2015), 541-554.

${ }^{38}$ Kazarian, A Chronology.

${ }^{39}$ Rouben P. Adalian (Director of the Armenian National Institute) in telephone conversation with the author, March 2012.

${ }^{40}$ See e.g. Peter Balakian, The Burning Tigris: The Armenian Genocide and America's Response (New York: Perennial, 2004); Michael Bobelian, Children of Armenia: A Forgotten Genocide and the Century-Long Struggle for Justice (New York: Simon \& Schuster, 2009); Raymond Kevorkian, The Armenian Genocide: A Complete History (London: I.B. Tauris, 2011); and Guenter Lewy, The Armenian Massacres in Ottoman Turkey: A Disputed Genocide (Salt Lake City: University of Utah Press, 2005).
} 
micro, macro, and meso levels as explained earlier in the article. ${ }^{41}$ Finally, we added latitude and longitude coordinates to the villages mentioned in the database and assigned the events described in the manuscript to the appropriate genocide stage according to Stanton's formulation (Figure 3). Once we began doing this, however, it quickly became apparent that rarely could an event be encapsulated using only one stage; in fact, some events required as many as six stages for adequate description. This, of course, confirms Stanton's point that multiple stages occur concurrently within a broad chronological narrative. Further complicating our work, some events included more than one village, province, district, etc.; we handled this problem by creating one entry in the dataset for each location mentioned during the description of a certain event. For example, some events started at one location, traveled through a second one, and ended up somewhere else. In this instance, we created three entries for one single event, each listing its location in the appropriate geographical scale. Some entries described events that occurred simultaneously in two or more locations; we handled these types of events in the same manner just described. We did experience a relative degree of uncertainty with the data, as is usually the case with historical documents used to create geographical databases. ${ }^{42}$ For example, if an event was described at the district, regional, or province scale, we treated it as affecting the district, region, or province as a whole, since specific locations were not available. This mode of analysis applies to the national scale as well. If an event occurred on a national scale, then we treated it as if it occurred uniformly across Turkey. We acknowledge the shortcoming of this technique but felt the contribution outweighed the uncertainty and relative inaccuracy.

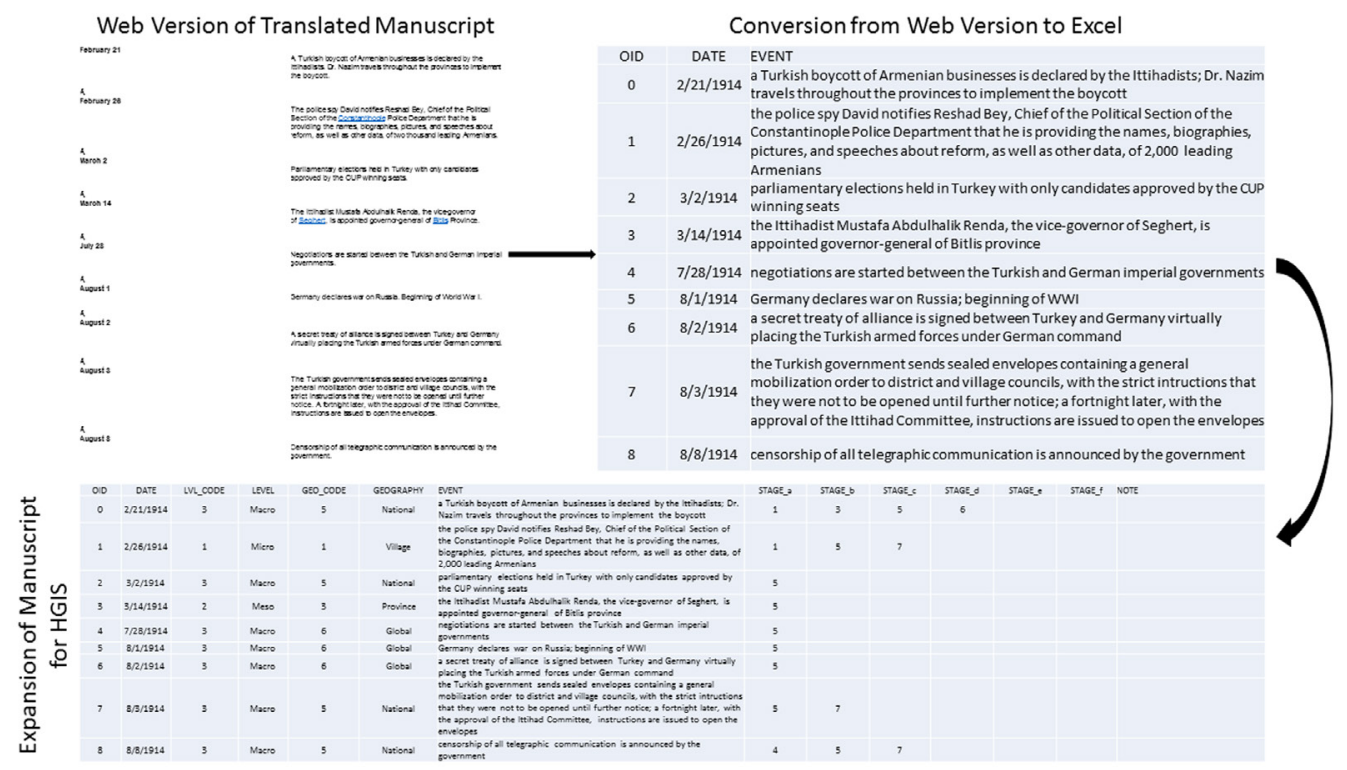

Figure 3. Transformation of the Kazarian manuscript into the GIS databases.

\section{Analysis and Geovisualization}

To gain a deeper understanding of the stages of the Armenian genocide, we grouped them into three phases - A, B, and C: where we categorized phase A to include classification (stage 1), symbolization (stage 2), discrimination (stage 3), and dehumanization (stage 4). This phase serves to create, identify, and isolate the perceived other. Phase B includes organization (stage 5), polarization (stage 6), and preparation (stage 7), and works to define phase A and implement phase $C$. Phase $C$ consists of both persecution (stage 8 ) and extermination (stage 9), which results in the destruction of the perceived other. We then graphed these phases by perpetrator level (Figure

\footnotetext{
${ }^{41}$ See Finkel and Straus, "Macro, Meso, and Micro Research.”

${ }^{42}$ See Ian N. Gregory and Paul S. Ell, Historical GIS: Technologies, Methodologies and Scholarship (Cambridge: University Press, 2007).
} 
4), noting a clear spike during 1915. This was to be expected as 1915 is the generally accepted beginning year of the Armenian genocide, however, we found activity at all three levels beginning in 1914 (Figure 4 and Table 2). If other genocides follow suit, it is possible to look for early indicators of genocide processes in anticipation of preventing the mass murder of targeted groups.

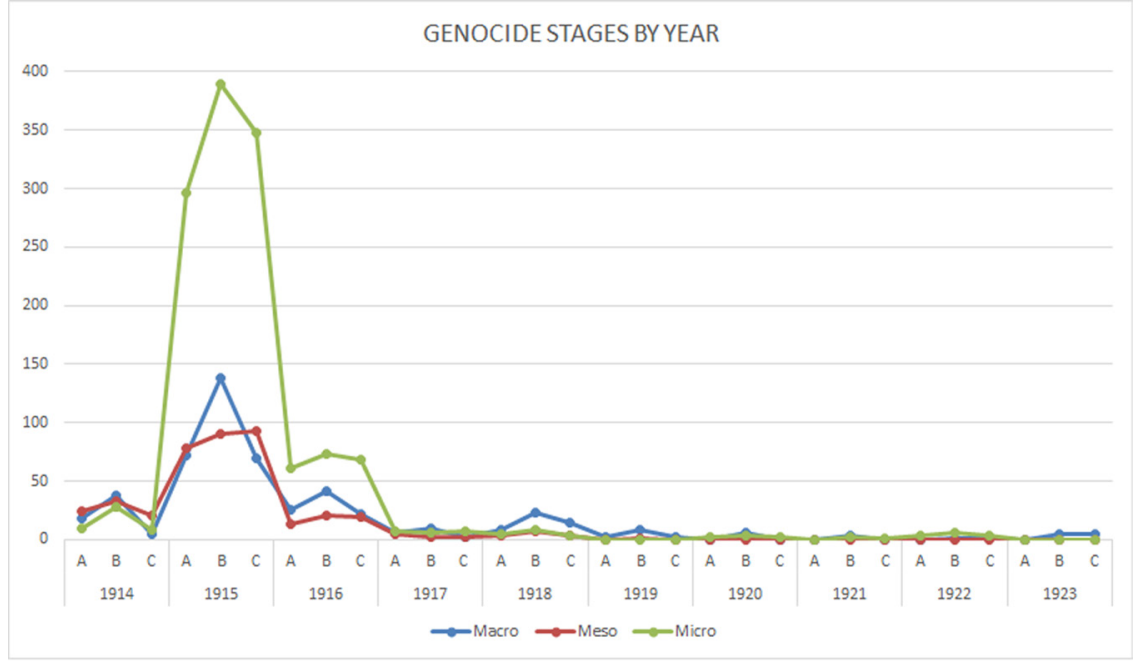

Figure 4. Graph of phase A, B, and C by macro, meso, and micro levels for year (1914-1923).

Table 2. Data by Phases.

\begin{tabular}{|c|c|c|c|c|c|c|c|c|c|c|c|c|c|c|c|}
\hline & \multicolumn{3}{|c|}{1914} & \multicolumn{3}{|c|}{1915} & \multicolumn{3}{|c|}{1916} & \multicolumn{3}{|c|}{1917} & \multicolumn{3}{|c|}{1918} \\
\hline & $A$ & $B$ & $\mathrm{C}$ & $A$ & $B$ & C & $A$ & $B$ & C & $A$ & $B$ & C & $A$ & $B$ & C \\
\hline Macro & 18 & 38 & 5 & 72 & 138 & 70 & 25 & 42 & 22 & 6 & 10 & 2 & 8 & 23 & 14 \\
\hline Meso & 24 & 33 & 21 & 78 & 90 & 93 & 13 & 20 & 19 & 5 & 2 & 2 & 3 & 7 & 3 \\
\hline \multirow[t]{3}{*}{ Micro } & 9 & 28 & 8 & 296 & 389 & 348 & 61 & 73 & 69 & 7 & 6 & 7 & 5 & 8 & 4 \\
\hline & \multicolumn{3}{|c|}{1919} & \multicolumn{3}{|c|}{1920} & \multicolumn{3}{|c|}{1921} & \multicolumn{3}{|c|}{1922} & \multicolumn{3}{|c|}{1923} \\
\hline & $A$ & $B$ & $\mathrm{C}$ & $A$ & $B$ & C & $A$ & $B$ & $\mathrm{C}$ & A & $B$ & C & A & $B$ & $\mathrm{C}$ \\
\hline Macro & 2 & 8 & 2 & 0 & 6 & 0 & 0 & 3 & 0 & 0 & 1 & 1 & 0 & 5 & 5 \\
\hline Meso & 0 & 1 & 0 & 0 & 0 & 0 & 0 & 0 & 0 & 0 & 0 & 0 & 0 & 0 & 0 \\
\hline Micro & 0 & 0 & 0 & 2 & 4 & 2 & 0 & 2 & 1 & 4 & 6 & 4 & 0 & 0 & 0 \\
\hline
\end{tabular}

For the first nine stages at all six scales, we accumulated 2243 total events (Table 3). As stated earlier, we assigned up to six stages per event. For example, on October 17, 1914, the entry reads, "bands of chetes begin looting, violating women and children, and large-scale murdering in Erzerum province." ${ }^{43}$ We assigned discrimination (stage 3), dehumanization (stage 4), organization (stage 5), preparation (stage 7), persecution (stage 8), and extermination (stage 9) to this single event that occurred at the province scale. This entry describes looting (stages 3 and 8), with the Armenian population singled out for harassment and persecution, as well as the violation of women and children (stages 4 and 8), which also served to dehumanize and persecute the victims. Organized and government-sanctioned bands of chetes perpetrated the violence (stage 5) in preparation (stage 7) for an escalation of violence that resulted in extermination (stage 9). This description of events corroborates el-Ghusein's description of witnessing women and children lying, dead or dying, along the road between Urfa and Erzerum. ${ }^{44}$ This early entry indicates multiple stages of genocidal processes working together in synthesis during a single event. In other words, we record extermination, a later stage in the model, by a meso-level perpetrator at the province scale, early in the Armenian genocide.

\footnotetext{
${ }^{43}$ Kazarian, A Chronology, entry for October 17, 1914.

${ }^{44}$ el-Ghusein, Martyred Armenia.
} 
Table 3. Stage Data by Scale.

\begin{tabular}{clcccccccc}
\hline STAGE & STAGE NAME & VIL & DIS & PROV & REG & NATL & GLO & TOTAL & PERCENT \\
$\mathbf{1}$ & Classification & 269 & 19 & 46 & 14 & 82 & 22 & 452 & $20.15 \%$ \\
$\mathbf{2}$ & Symbolization & 16 & 0 & 4 & 0 & 7 & 3 & 30 & $1.34 \%$ \\
$\mathbf{3}$ & Discrimination & 76 & 1 & 27 & 1 & 9 & 5 & 119 & $5.31 \%$ \\
$\mathbf{4}$ & Dehumanization & 23 & 3 & 8 & 0 & 3 & 0 & 37 & $1.65 \%$ \\
$\mathbf{5}$ & Organization & 330 & 18 & 69 & 13 & 134 & 68 & 632 & $28.18 \%$ \\
$\mathbf{6}$ & Polarization & 28 & 0 & 10 & 0 & 9 & 1 & 48 & $2.14 \%$ \\
$\mathbf{7}$ & Preparation & 158 & 8 & 23 & 9 & 58 & 4 & 260 & $11.59 \%$ \\
$\mathbf{8}$ & Persecution & 208 & 11 & 45 & 10 & 37 & 6 & 317 & $14.13 \%$ \\
$\mathbf{9}$ & Extermination & 231 & 17 & 41 & 13 & 36 & 10 & 348 & $15.51 \%$ \\
& $\quad$ TOTAL & 1339 & 77 & 273 & 60 & 375 & 119 & 2243 & \\
& PERCENT & $59.70 \%$ & $3.43 \%$ & $12.17 \%$ & $2.67 \%$ & $16.72 \%$ & $5.31 \%$ & &
\end{tabular}

At the village scale, we accumulated 1339 events that equated to 59.7 percent of the total number of events recorded. The high percentage of events at the village scale indicates that genocidal processes targeting and identifying victim groups was especially prevalent at this level. At the district scale, the percentage falls to a mere 3.43 percent of the total events indicating that this was a less important geographical scale, with comparably low rates at the regional (2.68 percent) and global (5.3 percent) scale. However, both the provincial (12.17 percent) and national (16.72 percent) levels record a substantial number of events. Of note, in this analysis as well as others, genocide appears to jump or skip geographical scales. ${ }^{45}$ Next, we take a closer look at the first nine stages across all scales.

Classification (stage 1) makes up 20.15 percent of the total events and comes in as second only to organization in the Kazarian manuscript. One example of a stage 1 entry at the village scale is that dated October 10, 1914 which reads: "In Zeitun, all the Armenian notables are called to a meeting; about three score attend and are immediately arrested." ${ }^{46}$ We also assigned discrimination (stage 3 ), organization (stage 5), and persecution (stage 8) to this entry showing how stages can form a symbiotic, mutually reinforcing relationship in the production of genocide. Because these stages intertwine so closely, we cannot disentangle them easily. We also see that macro-level perpetrators provide orders to meso-level perpetrators who carry out their instructions at the village scale. This entanglement of scales and perpetrators is typical of genocidal processes and also occurred frequently during the Holocaust. ${ }^{47}$

Symbolization (stage 2) makes up a little over 1 percent of total events, which is in stark contrast to the Holocaust, an event in which Nazi propaganda played a key role. ${ }^{48}$ In the Armenian case, even the minimal amount of symbolization produced was more insinuated than blatant. For example, on September 30, 1914, Kazarian's entry reads: “The government distributes arms to the Muslim residents of the town of Keghi in Erzerum province on the excuse that the Armenians there were unreliable." ${ }^{49}$ Here, we also assigned organization (stage 5), polarization (stage 6), and preparation (stage 7) to this entry. Early on (again, this is before 1915) in the genocide process, we see macro-level perpetrators (the government) arming and inciting micro-level perpetrators (individuals) at the village scale.

Discrimination (stage 3) accounts for about 5 percent of the total events across all scales. On February 21, 1915, the entry reads: "An attack by chetes on the village of Purk near ShabinKarahisar results in looting, murder, rape." ${ }^{50}$ Additionally, we assigned dehumanization (stage

\footnotetext{
${ }^{45}$ See Sallie A. Marston, "The Social Construction of Scale," Progress in Human Geography 24, no. 2 (2000), 219-242; Sallie A. Marston, John Paul Jones and Keith Woodward, "Human Geography Without Scale," Transactions of the Institute of British Geographers 30, no. 4 (2005), 416-432.

${ }^{46}$ Kazarian, A Chronology, entry for October 10, 1914.

${ }^{47}$ See in particular, Knowles, Cole and Giordano, Geographies of the Holocaust.

${ }^{48}$ Jeffrey Herf, The Jewish Enemy: Nazi Propaganda during World War II and the Holocaust (Cambridge, MA: Belknap Press, 2008).

${ }^{49}$ Kazarian, A Chronology, entry for September 30, 1914.

${ }^{50}$ Ibid., entry for February 21, 1915.
} 
4), organization (stage 5), persecution (stage 8), and extermination (stage 9) to this entry. With this event, we observed macro-level and meso-level perpetrators operating at the village level. The meso-level militias also functioned with impunity given to them by the government.

Dehumanization (stage 4) makes up a little over 1.5 percent of the total events and includes rape, torture, and hangings that served to demoralize victims and lessen them as human beings in the eyes of the general population. On April 3, 1915, the entry reads: "(Easter week) mass arrests and a search for weapons are carried out in Marash and Hadjin, with the seizure of all arms, including household knives; numerous rapes during the house searches are reported. ${ }^{\prime 51}$ Because this event mentions two villages, we count it twice in the database - once for the village of Marash and once for the village of Hadjin. In addition to dehumanization (stage 4), we assigned classification (stage 1), discrimination (stage 3), organization (stage 5), and persecution (stage 8) to the event. Interestingly, the perpetrators of these actions are not clearly identified, and could either be the national military (macro-level), chetes militias (meso-level), or the local police and citizens (microlevel). As we see from this example, it is possible for all three perpetrator levels to operate at the village scale.

Figures $5 a-5 d$ illustrate these first four stages at the village scale. The symbol size represents frequency, thus the larger the symbol, the more occurrences of that stage at that location. Classification occurs across all provinces, but especially in the eastern provinces as expected. However, both symbolization and dehumanization occur primarily in the eastern provinces and do not extend to the rest of the country. Discrimination occurs in the eastern provinces with some diffusion to the other provinces.

Organization (stage 5) makes up over a quarter of the total events at 28.18 percent. As expected, this stage shows a clear and active pattern of government (macro-level) involvement in the overall process of genocide, including in the capitol city of Constantinople. The stage includes arrests, custody, deportations, and the intent to annihilate carried out by any or all of the perpetrator levels. For example, the entry for June 3, 1915 states: "Ayub Bey, an arch-assassin, leaves Adana for Aleppo in connection with organizing massacres." 52 Based on the entry, we also assigned polarization (stage 6) and preparation (stage 7) to the event. This stage is where processes of genocide by attrition become most prominent and intent is ambiguous at best. Without explicit orders from the top, lower level perpetrators interpret these orders as they saw fit. Deportation alone does not imply murder; however, when perpetrators interpret deportation to mean long, hard marches through severe climates and hundreds of miles with no food, water, or supplies, then large-scale death naturally is produced.

Polarization (stage 6) makes up only about two percent of the total events. One example of polarization includes this entry from January 5, 1915:

The Turkish government publicly charges that Armenian bakers in the army bakeries of Sivas were poisoning the bread of the Turkish forces; the bakers are cruelly beaten, despite the fact that a group of doctors proves the charge to be false by examining the bread and even eating it; as this marks an attempt on the part of the government to incite massacre, the government does not rescind the charge..$^{53}$

We also assigned classification (stage 1), symbolization (stage 2), organization (stage 5), and persecution (stage 8) to this entry. At the village scale, we see an assertion of macro-level control in an attempt to incite violence against a targeted group by all levels of perpetrators.

Preparation (stage 7) makes up almost 12 percent of the total events. This stage includes any event that indicates the potential destruction of the Armenians. For instance, January 12, 1915 reads: "Ahmed Muammer, the governor-general of Sivas province, orders the destruction of Tavra-Koy and other strategically located villages around the city of Sivas to make future defense impossible

\footnotetext{
${ }^{51}$ Ibid., entry for April 3, 1915.

${ }^{52}$ Ibid., entry for June 3, 1915.

${ }^{53}$ Ibid., entry for January 5, 1915.
} 

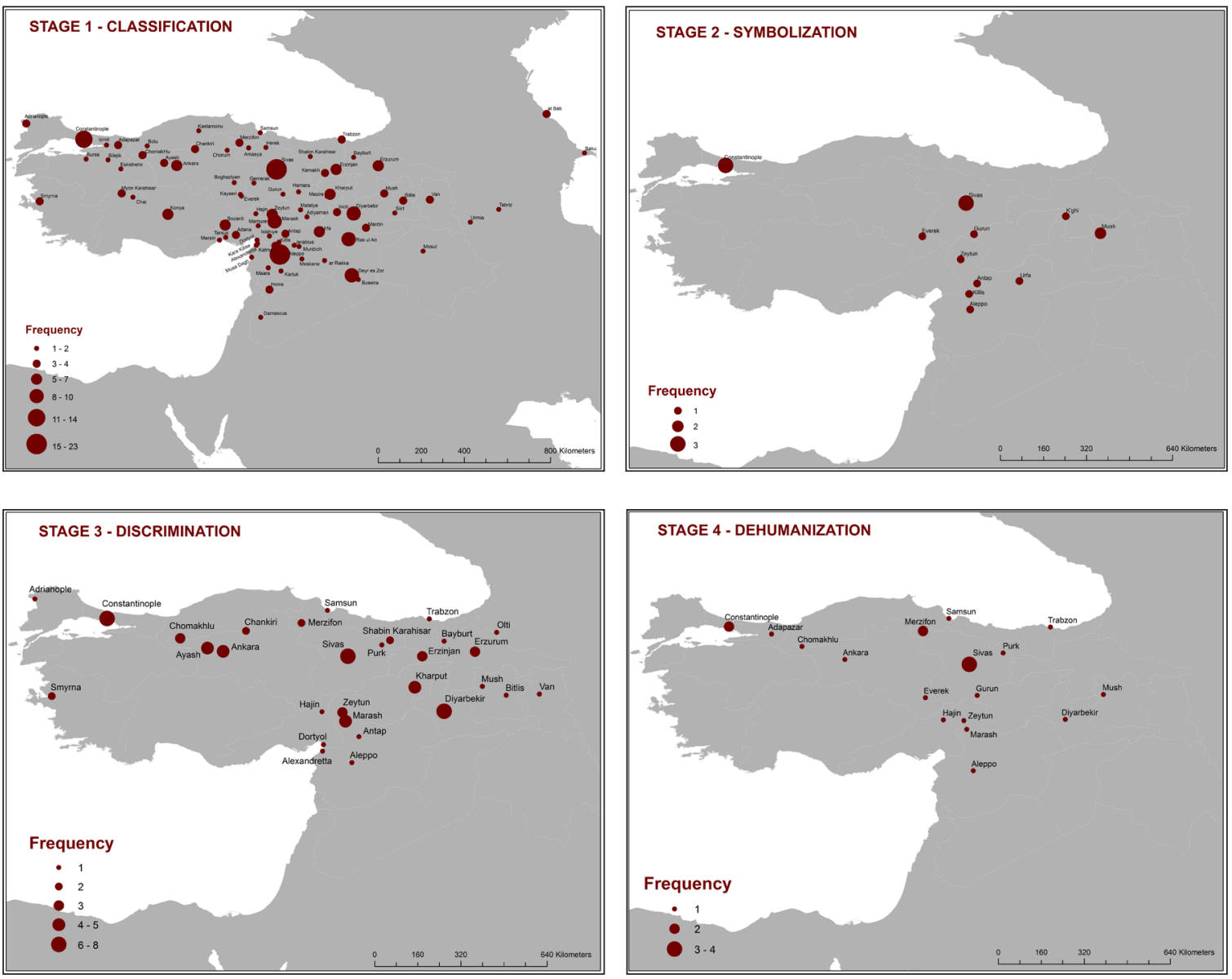

Figure 5. a. Stage 1; b. Stage 2; c. Stage 3; d. Stage 4.

for the Armenians; inside the city of Sivas strategically located buildings were requisitioned." 54 We assigned organization (stage 5) and persecution (stage 8) to this event as well. Again, we see the government's top-down production of genocidal processes carried out at the village scale. This event also provides an example of ambiguity. We do not know the exact villages included in addition to Tavra-Koy and Sivas. Consequently, we do not include them in our database or analysis.

Persecution (stage 8) makes up about 15.5 percent of the total events. This stage includes any indication of escalation of violence, especially physical violence, against the victims as opposed to material and property damage and destruction. On May 10, 1915, the entry reads: "The Armenian refugees from Zeitun found in Marash, who had previously been spared deportation, are removed to the Syrian Desert." ${ }^{55}$ We also included classification (stage 1), organization (stage 5), preparation (stage 7), and extermination (stage 9). Although this entry does not specifically mention murder, this offers another poignant example of genocide by attrition. The insinuation here is that most Armenians will not survive the deportation process to the harsh Syrian desert; thus, their numbers will be greatly reduced upon arrival, whereupon the survivors were promptly executed. Morgenthau describes scenes of victims dead or dying from violence, starvation, and exhaustion along the road in his memoir. ${ }^{56} \mathrm{He}$ argues that Turkish policy specifically provided for

\footnotetext{
${ }^{54}$ Ibid., entry for January 12, 1915.

${ }^{55}$ Ibid., entry for May 10, 1915.

${ }^{56}$ Henry Morgenthau, Ambassador Morgenthau's Story (Detroit: Wayne State University Press, 2003).
} 
extermination disguised as deportation, with death through attrition culling the number of victims along the way.

Figures $6 \mathrm{a}-6 \mathrm{~d}$ visualize the dispersion of stages 5 through 8 . Organization, preparation, and persecution display dispersed locations across the country indicating that these stages play a pivotal role in the processes of genocide as a whole. Polarization though is concentrated in the eastern provinces where most Armenians lived. ${ }^{57}$

${ }^{57}$ Melkonian, Javakhk: Historical Outline.
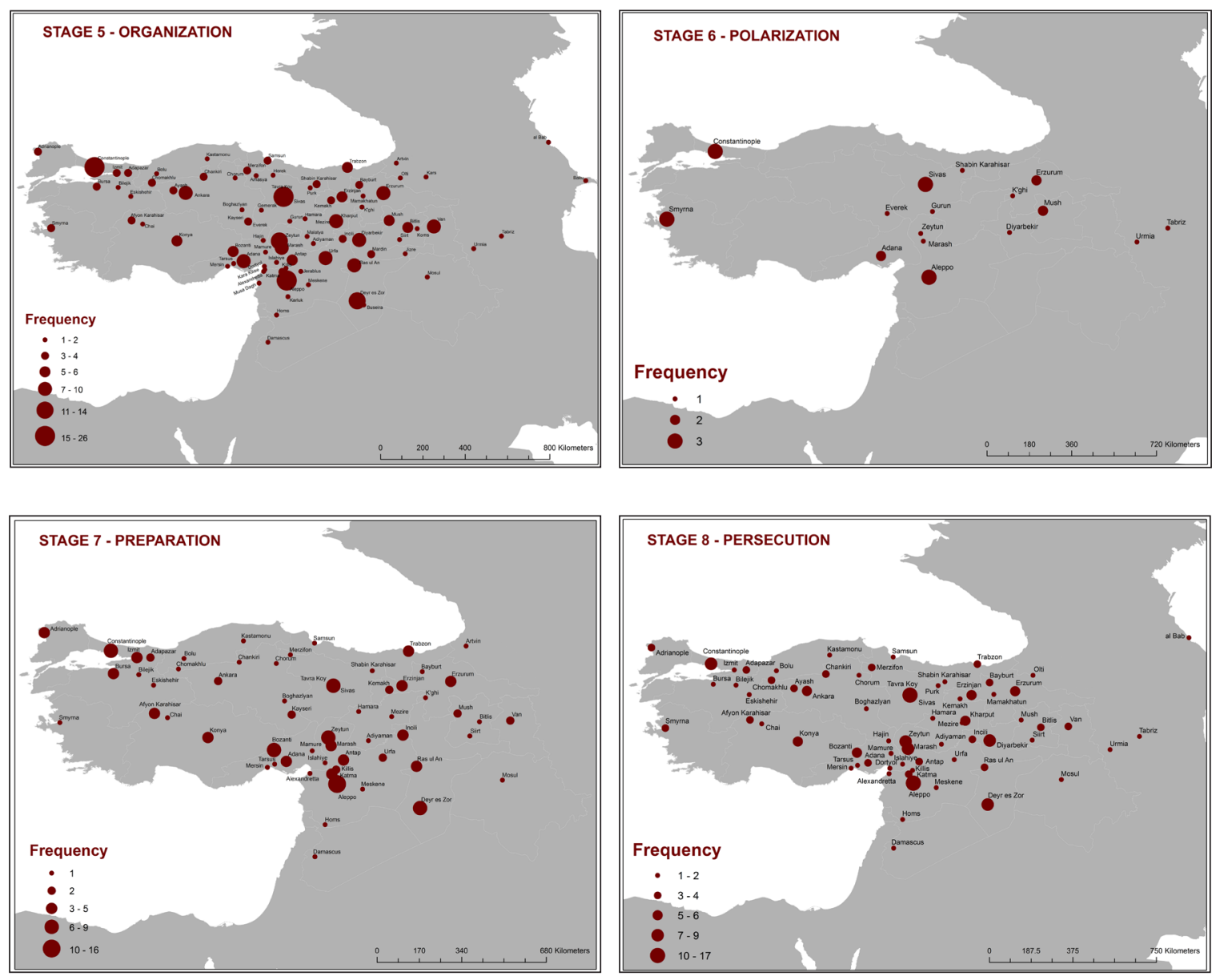

Figure 6. a. Stage 5 Organization; b. Stage 6 Polarization; c. Stage 7 Preparation; d. Stage 8.

Lastly, extermination (stage 9) places third in the overall percentage with 15.5 percent of total events. On March 1, 1916, the entry reads: "The Interior Ministry is informed from Aleppo that the Armenians who fled from Mardin had been killed." ${ }^{58}$ We also assigned classification (stage 1) and organization (stage 5) to this entry. This event illustrates the depth of government involvement at all scales, but especially at the village scale. Figure 7 shows the dispersion of extermination at the village scale. Extermination is a widespread stage and illustrates the intensity of the killing across the country.

${ }^{58}$ Kazarian, A Chronology, entry for March 1, 1916. 


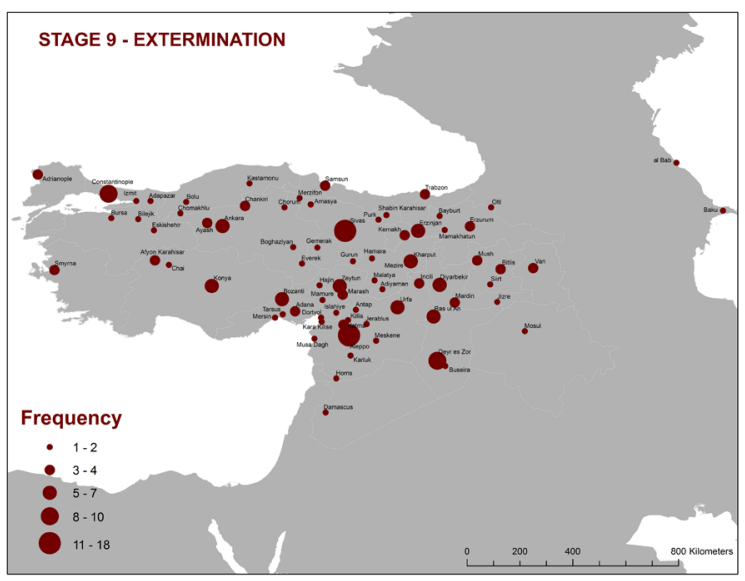

Figure 7. Stage 9 Extermination.

\section{Discussion}

In this article, we examine the spatio-temporal patterns of the Armenian genocide by stages. This allows us to conduct a structured investigation of the event and informs our understanding of possible clustering and diffusion processes that occurred during the genocide. This approach is designed to complement previous analyses organized around subjects such as the number of deaths by location, population, demographics, or the effects of specific polices. Moreover, these types of analyses are not conducive to the type of holistic approach we are interested in applying to the Armenian genocide.

The stage model of genocide offers several advantages. First, stages are a coherent method for describing the progression of genocide and allows for the exploration of large datasets of the type described in our case study. These stages help us organize and categorize the steps undertaken to destroy a targeted section of the population intentionally. Second, analysis by stages permits us to consider the genocide in its entirety from start to finish, unlike the recording of death statistics by location, which offers only a glimpse of the larger destruction of victim groups that took place dynamically over significant periods of time. By deconstructing genocide into smaller, quantifiable stages, we gain a unique view when compared to the whole-event perspective. In addition, this dissection is vital because it still allows us to present genocide as a complex process and to account for the dynamics of genocide by attrition. Our approach permits a perspective where the intent to kill, expressed or implied, is as fundamental to the process of genocide as the firing squad. We are thus able to examine where and when genocide by attrition processes start and how they diffuse across the country. We also assess the varying roles of perpetrators from the macro to micro levels, while still acknowledging the general progression of genocidal stages as events unfold. Third, there is no precedent in the literature for using a stage model in spatial analyses of genocide, but there have been calls for a deeper understanding of the structure and processes of genocide events. While each genocide is unique, there are fundamental similarities that allowed for the construction of general models. By deconstructing the whole event into stages based on location, we can open a dialog about how the processes are catalyzed, how they progress, and perhaps, what interrupts or disrupts them.

Our analysis shows clearly that all stages operate at varying levels throughout a genocide event. We saw clear examples of extermination early in 1914 while still seeing signs of classification much later in the genocide. Stanton's argument that his proposed stages interact and overlap dynamically then holds true, and we can argue there is no sequence of stages, but rather intensity levels that vary to construct genocidal processes. Within this context, it is clear that the stage of organization plays a quite significant role, thus exemplifying the key role that government participation plays in genocidal processes and the recurring theme of top-down authority structures bringing about genocide. Furthermore, in the Armenian case we witness the vital roles mid-level and meso-level perpetrators play in carrying out the genocidal directives of a central government. Seemingly, it 
takes the effective cooperation of all three perpetrator levels to implement and see through the extermination of a select group of people, with perpetration at the village or local geographical scale being especially key.

When assigning stages to events, we noticed that some events described in the Kazarian manuscript did not easily conform to Stanton's model. Cultural genocide appears very frequently in the events described, yet we lacked a stage to describe them. For instance, we see examples of Armenian monasteries burned, crosses destroyed and replaced by crescents, Turkish emigrants replacing Armenian villagers in ancestral homes, and forced Islamization. ${ }^{59}$ El-Ghusein describes Turkish emigrants from Roumelia moving into Zeitun to replace the Armenians, ${ }^{60}$ and there is also the widespread case of Armenian orphans turned over to Turkish families. All of these events contribute to the erasure of a culture from the landscape, and their effects persist long after actual killing events cease. Therefore, we advocate the addition of a stage to the current ten-stage model, encompassing and capturing events designed to destroy the culture of victim groups in order to describe more fully the Armenian genocide.

We found other events that Kazarian described that no stage adequately captured, including the roles of bystanders and roles of victims that the literature argues are under-represented and understudied. ${ }^{61}$ Within the manuscript, we see victims encouraging cooperation with the demands and abuses, and we see dissent and violence perpetrated against the Turks. ${ }^{62}$ For example, el-Ghusein describes a scene at Urfa where the Armenians refused to surrender their weapons and resisted arrest by killing several of the soldiers. ${ }^{63}$ Balakian further corroborates participation by bystanders, such as United States Ambassador Morgenthau, and acknowledges resistance by Armenian victims in Zeitun. ${ }^{64}$ Perhaps a set of victim indicators could help with the anticipation of the escalation of violence toward mass murder and genocide.

Bystanders on the global scale play a very active role in Kazarian's manuscript, especially with World War I as the backdrop to the Armenian genocide. We see examples of German attempts at controlling the carnage as well as ambassadors and soldiers reporting atrocities to their superiors, although Morgenthau reports that the Germans did little to stop the killing, at times even actively encouraging the maltreatment of Armenians. ${ }^{65}$ Instances of newspaper reports and aid from the global community to Turkey are also mentioned in Kazarian's manuscript. ${ }^{66}$ Overall, the global community appeared critical of the Turks' treatment of Armenians and other minority groups; however, the Turkish government largely ignored such protestations and continued to proceed with their genocidal actions.

\section{Conclusion}

This article employs a mixed methods approach by combining HGIS quantitative tools and a qualitative historical manuscript to augment the current literature on genocide and mass murder events. This approach helps bridge a divide in the quantitative-versus-qualitative narrative by benefiting from the strengths of each while attempting to minimize their weaknesses. Geographers and historians benefit from the emergence of HGIS and, through a multidisciplinary approach, gain a better understanding of genocidal events - such as the Holocaust ${ }^{67}$ - through the integration of a spatial component to explore and expand causal relationships. ${ }^{68}$ This project presents a

\footnotetext{
${ }^{59}$ Kazarian, A Chronology, entries for December 23, 1914; April 8, 1915; May 22, 1915; and January 24, 1916.

${ }^{60} \mathrm{el}$-Ghusein, Martyred Armenia.

${ }^{61}$ Tim Cole, Holocaust City: The Making of a Jewish Ghetto (New York: Routledge, 2003).

${ }^{62}$ Kazarian, A Chronology, entries for September 11, 1914; February 15, 1915; March 9, 1915; and March 14, 1915; and April 17, 1915.

${ }^{63}$ el-Ghusein, Martyred Armenia.

${ }^{64}$ Grigoris Balakian, Armenian Golgotha, trans. Peter Balakian and Aris Sevag (New York: Knopf, 2009); Morgenthau, Ambassador Morgenthau's Story.

${ }^{65}$ Morgenthau, Ambassador Morgenthau's Story.

${ }^{66}$ Kazarian, A Chronology, entries for March 31, 1915; May 6, 1915; May 24, 1915; July 23, 1915; and September 7, 1915.

${ }^{67}$ Knowles, Cole and Giordano, Geographies of the Holocaust.

${ }^{68}$ Jordi Marti-Henneberg, "Geographical Information Systems and the Study of History," Journal of Interdisciplinary History
} 
geographer's method to a comingled geohumanities topic using GIScience techniques to study the validity of a stage-based approach to genocide when describing the processes and structures of genocidal events. We approach HGIS projects with full awareness of our presuppositions, and are determined to allow the empirical spatial data to guide our analytical process, regardless of whether the results align with or contradict our preexisting understandings of the Armenian genocide.

Our examination of the Armenian genocide is based on the Kazarian manuscript ${ }^{69}$ and our extraction of geospatial information from this personal narrative is framed according to Stanton's stage model of genocide..$^{70}$ The mixed-method approach to a spatial understanding of the Armenian genocide contributes to the literature in more than one way. Kwan and Ding argue that GIS techniques serve to validate the information garnered from qualitative sources such as historical documents and manuscripts. ${ }^{71}$ Our visualization of stage events during the Armenian genocide substantiates evidence in the literature demonstrating that Turkish efforts concentrated the brunt of their efforts to eliminate the Armenian population within the eastern portion of Turkey. We also observed widely diffused processes at work, in particular the stage of organization (stage 5), which was prevalent across scale and perpetrator-levels.

A process-based understanding of genocide helps guide our research, as encouraged by Rosenberg, especially the concept of genocide by attrition. ${ }^{72}$ In our study, we found evidence of genocide by attrition in Kazarian's manuscript: the process of issuing government orders to clear an area, for example, lends itself to a means of deniability at the macro-level through interpretation by mid-level or meso-level perpetrators who allow disease, distance, dehydration, starvation, and harsh environments to exterminate their victims. Genocide by attrition thus provides a framework that helps us identify intent where denial abounds. ${ }^{73}$

In this article, we illustrate one method of exploring genocide in conjunction with HGIS by using a case study. Case studies typically examine one incident or example of an event at a certain time. In the social sciences, researchers use case studies often and extensively, and we argue that case studies are becoming an increasingly useful tool in multi-disciplinary research ${ }^{74}$ However, case studies do present their own set of disadvantages: for example, drawing definitive conclusions from a single case study is difficult, if not often impossible. But, as Yin argues, a single case study can add to the literature by challenging, extending, or confirming theoretical assumptions. ${ }^{75}$ Case studies provide a reliable and valid method of studying phenomena, and they offer an alternative to a group focus, or in our case, a whole-event focus. ${ }^{76}$

Using a case study in HGIS is predicated upon the availability of large datasets and is a long, complicated, and often tedious process. The datasets, however large they might be, are necessarily incomplete and contains an unavoidable element of uncertainty and inaccuracy, with the associated problems of drawing specific conclusions from them. For this reason, we recommend using geographic datasets of historical events, such as the Armenian genocide, to make general observations about a specific event: HGIS is for the identification of spatio-temporal patterns rather than the localized knowledge of a single fact. We, therefore, argue that a handful of errors does not change the overall patterns observed in our analysis of the Armenian genocide as recorded in the Kazarian manuscript; rather, the results of the analysis provide a framework within which single facts can be placed with the objective of examining how individual events relate to other events, both temporally (see Figure 4) and spatially (see Figures 5, 6, and 7). The Kazarian manuscript

\footnotetext{
XLII, no. 1 (2011), 1-13.

${ }^{69}$ Kazarian, A Chronology.

${ }^{70}$ See Stanton, “The Eight Stages of Genocide"; Stanton, "The Ten Stages of Genocide."

${ }^{71}$ Mei-Po Kwan and Guoxiang Ding, " Geo-Narrative: Extending Geographic Information Systems for Narrative Analysis in Qualitative and Mixed-Method Research," Professional Geographer 60, no. 4 (2008), 443-465.

${ }^{72}$ Rosenberg, "Genocide is a Process."

${ }^{73}$ See Fein, "Genocide by Attrition"; Rosenberg, "Genocide is a Process."

${ }^{74}$ See e.g. Knowles, Cole and Giordano, Geographies of the Holocaust.

${ }^{75}$ Robert K. Yin, Case Study Research: Design and Methods (Los Angeles: Sage Publications, 2013).

${ }^{76}$ Bent Flyvbjerg, “Five Misunderstandings About Case-Study Research," Qualitative Inquiry 12, no. 2 (2006), 219-245.
} 
provides a glimpse into 1914 Turkey through the eyes of an Armenian journalist that documented events he read or heard about; as such, it can be employed both as documentary material and as a case study that allows us the usefulness of genocide stage models.

Stage-based models break down genocide events into processes or phases in an attempt to move towards eventual prevention. Shaw argues for a focus on this structure for genocide research. ${ }^{77}$ In this study, we observed notable acts of violence that occurred before the historically recognized start of the Armenian genocide in 1915. By monitoring pre-cursor events in places atrisk for genocide and reacting without hesitation, prevention may become feasible. ${ }^{78}$ Furthermore, by combining perpetrator-level activities with Stanton's stage-based model of genocide we concluded that the village scale was the most significant scale for the diffused processes involved in the removal and destruction of minority ethnic groups in Turkey. Most importantly, we found that all three perpetrator-levels worked across multiple geographic scales to carry out the genocide event. Each perpetrator thus played a crucial role in the overall process toward the common goal of creating a homogenous state.

As with other HGIS projects, uncertainty and ambiguity pervades our historical data and sources. ${ }^{79}$ However, we believe that despite this lack of certainty, certain general spatial and temporal conclusions can be drawn concerning the Armenian genocide. These conclusions relate to the visualization and spatial relationships between processes involved in this genocide, relevant locations, and the period of time during which it took place. ${ }^{80}$ Through HGIS, we compiled historic source material into geospatial databases that are expandable, verifiable, and sharable for further research possibilities. In this article, we have not analyzed the full scale of the forced migration events that took place during the Armenian genocide due to length constraints. In future work, however, we plan on delving into a deeper analysis of this mass forced migration including the flow of migration along routes through the desert and the various effects of this migration on the victims. We intend to further explore the role of genocide by attrition through these forced marches using witness testimony to further corroborate the Kazarian manuscript and verify areas of uncertainty or ambiguity within the current dataset. We argue that collaboration is an essential part of successful HGIS projects and advocate for more multi-disciplinary research to foster an exchange of ideas and techniques.

\section{Bibliography}

Akçam, Taner. A Shameful Act: The Armenian Genocide and the question of Turkish Responsibility. New York: Henry Holt \& Co., 2006.

From Empire to Republic: Turkish Nationalism and the Armenian genocide. London: Zed Books, 2004.

Armenian National Institute. "Map of the 1915 Armenian Genocide in the Turkish Empire." Accessed March 11, 2016. http://www.armenian-genocide.org/map-full.html.

Balakian, Grigoris. Armenian Golgotha. Translated by Peter Balakian and Aris Sevag. New York: Knopf, 2009.

Balakian, Peter. The Burning Tigris: The Armenian Genocide and America's Response. New York: Perennial, 2004.

Beorn, Waitman, Tim Cole, Simone Gigliotti, Alberto Giordano, Anna Holian, Paul B. Jaskot, Anne Kelly Knowles, Marc Masurovsky, Erik B. Steiner. "The Geography of the Holocaust." Geographical Review 99, no. 4 (2009): 563-574. https://doi.org/10.1111/j.1931-0846.2009. $\underline{\mathrm{tb} 00447 . x}$

\footnotetext{
77 Shaw, "From Comparative to International Genocide Studies."

${ }^{78}$ Birger Heldt, "Mass Atrocities Early Warning Systems: Data Gathering, Data Verification and Other Challenges," in Guiding Principles of the Emerging Architecture Aiming at the Prevention of Genocide, War Crimes, and Crimes Against Humanity, Tetsushi Ogata and Andrew Zemlan, eds. 13-32 (Arlington, Virginia: George Mason University School of Conflict Analysis and Resolution, 2012); Nicolas Rost, "Will it Happen Again? On the Possibility of Forecasting the Risk of Genocide," Journal of Genocide Research 15, no. 1 (2013), 41-67.

${ }^{79}$ See generally Gregory and Ell, Historical GIS; see also e.g. Burleson and Giordano, "Extending Metadata Standards."

${ }^{80}$ Marti-Henneberg, "Geographical Information Systems."
} 
Bobelian, Michael. Children of Armenia: A Forgotten Genocide and the Century-Long Struggle for Justice. New York: Simon \& Schuster, 2009.

Burleson, Shelley and Alberto Giordano. "Extending Metadata Standards for Historical GIS Research: A Case Study of the Holocaust in Budapest and the Armenian Genocide in Turkey." International Journal of Applied Geospatial Research 6, no. 4 (2015): 88-109. https://doi.org/10.4018/ijagr.2015100105

Charny, Israel W. How Can we Commit the Unthinkable? Genocide: The Human Cancer. Boulder: Westview Press, 1982.

Cole, Tim. Holocaust City: The Making of a Jewish Ghetto. New York: Routledge, 2003.

Cole, Tim and Graham Smith. "Ghettoization and the Holocaust: Budapest 1944." Journal of Historical Geography 21, no. 3 (1995): 300-316. https://doi.org/10.1006/jhge.1995.0021

Cooper, Allan D. The Geography of Genocide. Lanham: University Press of America, 2009.

Cope, Meghan and Sarah Elwood, editors. Qualitative GIS: A Mixed Method Approach. Los Angeles: Sage, 2009. https://doi.org/10.4135/9780857024541

Dadrian, Vahakn N. The History of the Armenian Genocide: Ethnic Conflict from the Balkans to Anatolia to the Caucasus. New York: Berghahn Books, 2003.

DIVA-GIS. Accessed September 25, 2015. http://www.diva-gis.org/gdata.

el-Ghusein, Fa'iz. Martyred Armenia. New York: George H. Doran Company, 1918.

Fein, Helen. Accounting for Genocide: Victims - and Survivors - of the Holocaust. New York: Free Press, 1979.

-------. “Genocide by Attrition 1939-1993: The Warsaw Ghetto, Cambodia, and Sudan: Links Between Human Rights, Health, and Mass Death." Health and Human Rights 2, no. 2 (1997): 10-45. https://doi.org/10.2307/4065270

Finkel, Evgeny and Scott Straus. "Macro, Meso, and Micro Research on Genocide: Gains, Shortcomings, and Future Areas of Inquiry." Genocide Studies and Prevention: An International Journal 7, no. 1 (2012): 56-67. https://doi.org/10.3138/gsp.7.1.56

Flyvbjerg, Bent. "Five Misunderstandings About Case-Study Research." Qualitative Inquiry 12, no. 2 (2006): 219-245. https://doi.org/10.1177/1077800405284363

Giordano, Alberto and Tim Cole. "On Place and Space: Calculating Social and Spatial Networks in the Budapest Ghetto." Transactions in GIS 15, no. s1 (2011): 143-170. https://doi.org/10.1111/ j.1467-9671.2011.01262.x

Goldhagen, Daniel J. Worse than War: Genocide, Eliminationism, and the Ongoing Assault on Humanity. New York: Public Affairs, 2009.

Gonzalez-Puente, Marc, Minerva Campos, Mike K. McCall, and Jose Munoz-Rojas. "Places Beyond Maps: Integrating Spatial Map Analysis and Perception Studies to Unravel Landscape Change in a Mediterranean Mountain Area (NE Spain)." Applied Geography 52 (2014): 182-190. https://doi.org/10.1016/j.apgeog.2014.05.010

Goodchild, Michael F. and Donald G. Janelle. "Toward Critical Spatial Thinking in the Social Sciences and Humanities." GeoJournal 75, no. 1 (2010): 3-13. https://doi.org/10.1007/s10708-010-9340-3

Gregory, Ian N. and Paul S. Ell. Historical GIS: Technologies, Methodologies and Scholarship. Cambridge: Cambridge University Press, 2007. https://doi.org/10.1017/CBO9780511493645

Harff, Barbara. "No Lessons Learned from the Holocuast? Assessing Risks of Genocide and Political Mass Murder Since 1955." American Political Science Review 97, no. 1 (2003): 57-73. https://doi.org/10.1017/S0003055403000522

Heldt, Birger. "Mass Atrocities Early Warning Systems: Data Gathering, Data Verification and Other Challenges." In Guiding Principles of the Emerging Architecture Aiming at the Prevention of Genocide, War Crimes, and Crimes Against Humanity, edited by Tetsushi Ogata and Andrew Zemlan, 13-32. Arlington, Virginia: George Mason University School of Conflict Analysis and Resolution, 2012. https://doi.org/10.2139/ssrn.2028534

Herf, Jeffrey. The Jewish Enemy: Nazi Propaganda during World War II and the Holocaust. Cambridge, Massachusetts: Belknap Press, 2008.

Hewsen, Robert H. Armenia: A Historical Atlas. Chicago: University of Chicago Press, 2001.

Hovannisian, Richard G. Remembrance and Denial: The Case of the Armenian genocide. Detroit: Wayne State University Press, 1998. 
Huber, R. "Empire Ottoman: Division Administrative." Library of Congress. 1899. Accessed October 10, 2015. https://lccn.loc.gov/2007633930.

Jung, Jin-Kyu and Sarah Elwood. "Extending the Qualitative Capabilities of GIS: Computer-Aided Qualitative GIS." Transactions in GIS 14, no. 1 (2010): 63-87. https://doi.org/10.1111/j.14679671.2009.01182.x

Kazarian, Haigazn K. A Chronology of the Armenian Genocide. Translated by R.P. Adalian. Washington DC: Armenian National Institute, 1923.

Kevorkian, Raymond. The Armenian Genocide: A Complete History. London: I.B. Tauris, 2011.

Kiernan, Ben. Blood and Soil: A World History of Genocide and Extermination from Sparta to Darfur. New Haven: Yale University Press, 2009.

Knowles, Anne Kelly, Tim Cole, and Alberto Giordano, editors. Geographies of the Holocaust. Bloomington: Indiana University Press, 2014.

Kuper, Leo. Genocide: Its Political Use in the Twentieth Century. New Haven: Yale University Press, 1981.

Kwan, Mei-Po and Guoxiang Ding. "Geo-Narrative: Extending Geographic Information Systems for Narrative Analysis in Qualitative and Mixed-Method Research." Professional Geographer 60, no. 4 (2008): 443-465. https://doi.org/10.1080/00330120802211752

Lemkin, Raphael. "Genocide." American Scholar 15, no. 2 (1946): 227-230.

-------. "Genocide: A Modern Crime." Free World 4 (1945): 39-43.

Lewy, Guenter. The Armenian Massacres in Ottoman Turkey: A Disputed Genocide. Salt Lake City: University of Utah Press, 2005.

Madden, Marguerite and Amy Ross. "Genocide and GIScience: Integrating Personal Narrative and Geographic Science to Study Human Rights." Professional Geographer 61, no. 4 (2009): 508-526. https://doi.org/10.1080/00330120903163480

Marston, Sallie A. "The Social Construction of Scale." Progress in Human Geography 24, no. 2 (2000): 219-242. https://doi.org/10.1191/030913200674086272

Marston, Sallie A., John Paul Jones and Keith Woodward. "Human Geography Without Scale." Transactions of the Institute of British Geographers 30, no. 4 (2005): 416-432. https://doi. org/10.1111/j.1475-5661.2005.00180.x

Marti-Henneberg, Jordi. "Geographical Information Systems and the Study of History." Journal of Interdisciplinary History XLII, no. 1 (2011): 1-13. https://doi.org/10.1162/JINH a 00202

Melkonian, Ashot. Javakhk: Historical Outline. Translated by T. Sonentz-Papazian. Boston: HyBooksOnline, 2009.

Morgenthau, Henry. Ambassador Morgenthau's Story. Detroit: Wayne State University Press, 2003.

Rosenberg, Sheri P. "Genocide is a Process, Not an Event." Genocide Studies and Prevention 7, no. 1 (2012): 16-23. https://doi.org/10.3138/gsp.7.1.16

Rost, Nicolas. "Will it Happen Again? On the Possibility of Forecasting the Risk of Genocide." Journal of Genocide Research 15, no. 1 (2013): 41-67. https://doi.org/10.1080/14623528.2012.759398

Schimmer, Russell. "Tracking the Genocide in Darfur: Population Displacement as Recorded by Remote Sensing." Yale Center for International and Area Studies: Genocide Studies Working Paper no. 36 (2008).

Seegers, Jennet and Alberto Giordano. "Cartographic Constructs: A Case Study of Nantucket Island Oral Histories." Professional Geographer 67, no. 4 (2015): 541-554. https://doi.org/10.1 $\underline{080 / 00330124.2015 .1053835}$

Shaw, Martin. "From Comparative to International Genocide Studies: The International Production of Genocide in 20th-Century Europe." European Journal of International Relations 18, no. 4 (2011): 645-668. https://doi.org/10.1177/1354066111400926

Stanton, Gregory H. “The Eight Stages of Genocide.” 1996. Genocide Watch. Accessed October 16, 2016. http://www.genocidewatch.org/genocide/8stagesofgenocide.html.

-------. "The Ten Stages of Genocide." 2013. Genocide Watch. Accessed October 16, 2016. http://www.genocidewatch.org/genocide/tenstagesofgenocide.html.

Venkatesh, Viswanath, Susan A. Brown, and Hillol Bala. "Bridging the Qualitative-Quantitative Divide: Guidelines for Conducting Mixed Methods Resesarch in Information Systems." MIS Quarterly 37, no. 1 (2013): 21-54. 
Verpoorten, Marijke. Detecting Hidden Violence: The Spatial Distribution of Excess Mortality in Rwanda," Political Geography 31, no. 1 (2012): 44-56. https://doi.org/10.1016/j. polgeo.2011.09.004

Waller, James. Becoming Evil: How Ordinary People Commit Genocide and Mass Killing. New York: Oxford University Press, 2007.

Yin, Robert K. Case Study Research: Design and Methods. Los Angeles: Sage Publications, 2013. 